\title{
Fine structure of the apicomplexa oocyst of Nematopsis sp. of two marine bivalve molluscs
}

\author{
C. Azevedo ${ }^{1}$, R. Cachola ${ }^{2}$ \\ ${ }^{1}$ Department of Cell Biology, Institute of Biomedical Sciences, University of Oporto, Lg. A. Salazar no. 2, P-4000 Porto, \\ Portugal \\ ${ }^{2}$ National Institute of Fisheries Research, P-8000 Faro, Portugal
}

\begin{abstract}
The fine structure of an apicomplexan parasite oocyst found in gill tissues of 2 bivalve molluscs (Cerastoderme edule and Ruditapes decussatus) from Portugal is described. Monozoic oocysts, composed of a dense ellipsoidal wall with $0.35 \mu \mathrm{m}$ thickness containing a single vermiform uninucleated sporozoite, were $13.3 \times 4.5 \mu \mathrm{m}$. The apical zone of the wall contained a circular micropyle covered by a conical operculum. Externally the wall was surrounded by numerous thick and long microfibrils attached to the wall and connected to the host cell. The sporozoite occupied the internal oocyst lumen amidst fine granular material. Subsequently, the gradual disappearance of the attached microfibrils of the oocyst wall concomitantly with the degeneration and disintegration of the host cells was interpreted as a sign that this apicomplexan species was pathogenic to these host species. Lacking observation of different life cycle stages and other hosts, identification of the species of this apicomplexan gregarine of genus Nematopsis was not possible.
\end{abstract}

\section{INTRODUCTION}

A considerable number of publications on the life cycle of apicomplexan parasites of marine bivalve species has appeared over several years (see reviews by Théodoridès 1962, Sprague 1970, Lauckner 1983). However, few works describe ultrastructure of the apicomplexan. Among the apicomplexan parasites, the gregarine species are one of the most important bivalve pathogens. Sprague (1970), restored the 2 distinct gregarine genera, Nematopsis and Porospora, in consideration of significant differences between them. Later, Vivarès (1971), studying several Mediterranean species of these 2 genera, noted that it was difficult to distinguish between them. The controversial taxonomic position among some species of the order Eugregarinida was reported by Desportes et al. (1977), who considered the genus Nematopsis a synonym of Porospora.

The aim of the present work is to contribute a better knowledge of the ultrastructure of a part of the life cycle of Nematopsis sp., an apicomplexan species described for the first time in 2 marine bivalve molluscs from Portugal. Additionally, the ultrastructural disorganization and disintegration of host cells containing the oocysts is observed and discussed.

\section{MATERIAL AND METHODS}

Several parasitized specimens of the cockle Cerastoderme edule (Mollusca, Bivalvia) obtained in the estuarine region of southern Portugal between June and September from populations with high mortalities were used for light (LM) and transmission electron microscopy (TEM). For TEM, small pieces of the heavily infected gills were fixed in $3 \%$ glutaraldehyde in $0.2 \mathrm{M}$ sodium cacodylate buffer $(\mathrm{pH} 7.6)$ for $3 \mathrm{~h}$ at $4{ }^{\circ} \mathrm{C}$, washed for $2 \mathrm{~h}$ at $4{ }^{\circ} \mathrm{C}$ in the same buffer and post-fixed in buffered $2 \% \mathrm{OsO}_{4}$ for $2 \mathrm{~h}$ at $4{ }^{\circ} \mathrm{C}$. All pieces were dehydrated by a graded series of ethanol and embedded in Epon. After double-staining with uranyl acetate and lead citrate, the ultrathin sections were observed in a JEOL 100 CXII TEM operated at $60 \mathrm{kV}$.

A similar study on the clam Ruditapes decussatus (Mollusca, Bivalvia), obtained in the same estuarine region, was made during the same months.

\section{RESULTS}

A parasitic form existing in the gill connective tissue of the 2 bivalves was observed by light microscopy (Fig. 1). This parasite occurs mainly during the months of 


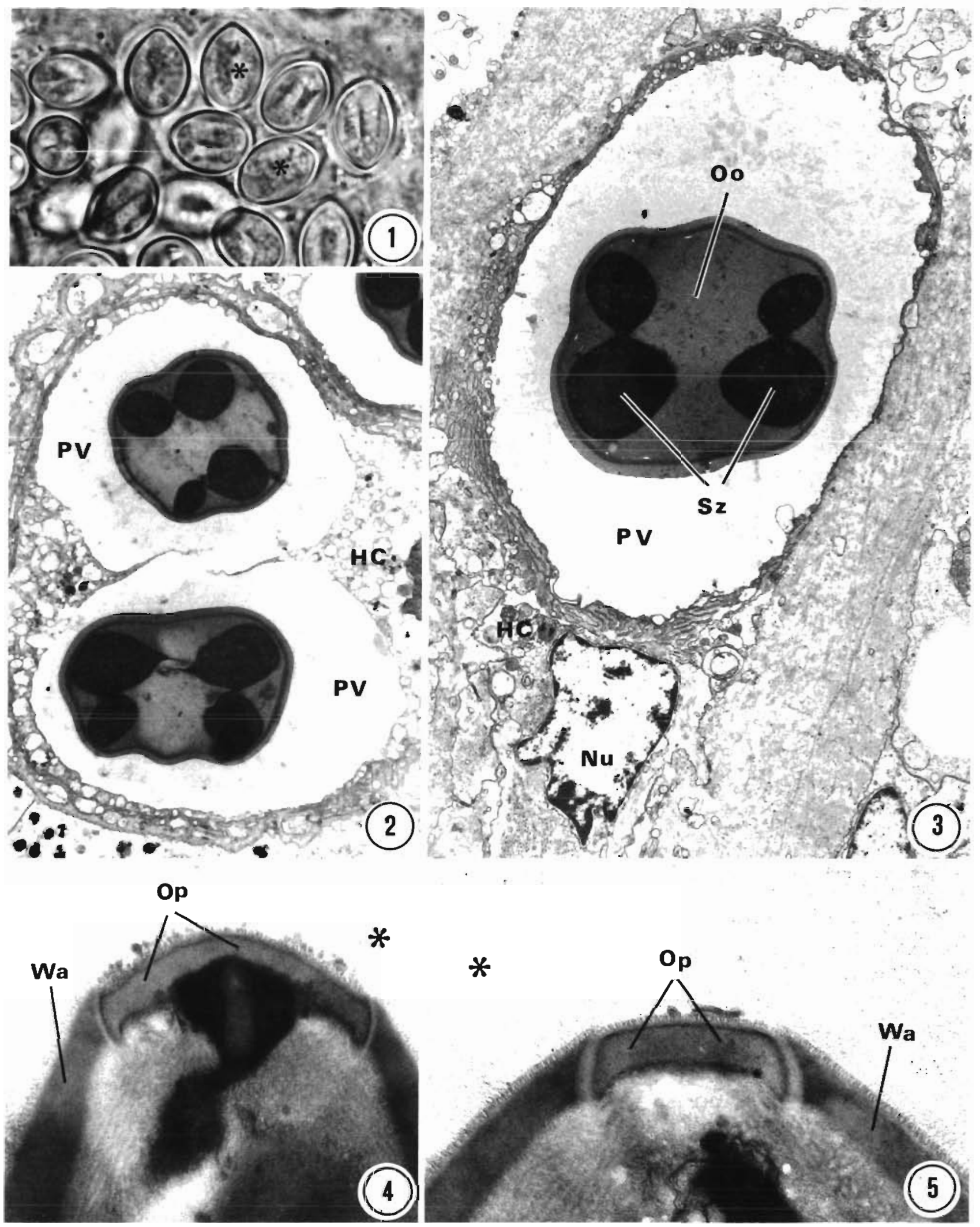


June to September with prevalences as high as $82 \%$ in Cerastoderme edule. The infection seemed more intense in larger specimens. The prevalence of oocysts in Ruditapes decussatus was very low $(8 \%)$. The para. site was represented by numerous dense oocysts distributed irregularly in the gill connective tissue (Figs. 1 \& 2). Each oocyst was contained within a parasitophorous vacuole of irregular outline and bound by a single thickened membrane (Figs. $2 \& 3$ ) The surrounding cytoplasm of the host cell contained a distinct endoplasmic reticulum just beneath the parasitophorous membrane (Fig. 3). The oocyst was $13.3 \mu \mathrm{m}$ long and $4.5 \mu \mathrm{m}$ wide $(\mathrm{n}=25)$ as measured in LM (Fig. 1) sections and in ultrathin serial sections. Each oocyst wall contained a single vermiform uninucleated sporozoite accommodated in the oocyst lumen, presenting an irregular outline and a dense cytoplasm (Figs. $2 \& 3$ ). The space of the oocyst lumen contained an electron-lucent material of moderate density (Figs. 3 to 7 j. The oocyst wall was $0.35 \mu \mathrm{m}$ thick and limited by 2 homogeneous layers. The polar end, where the circular micropyle was located, was thinner and composed only of 1 layer of dense material. The external layer was less dense than the inner one, which was in contact with the oocyst lumen containing the sporozoite (Fig. 7). The conical operculum that covered the micropyle was formed by the same material as the internal layer of the wall (Figs. $4 \& 5$ ). The external zone of the oocyst wall was surrounded by short microfibrils projected parallel to the external zone of the wall forming a regular thin layer (ca $50 \mathrm{~nm}$ thick) (Figs. 5 to 7 ). Numerous microfibrils projected towards the parasitophorous vacuole and directly contacted the membrane of the host cell vacuole (Fig. 3). In more advanced lysed stages of the host cells the parasitophorous membrane disappeared and some aspects of lysis were observed in the host cell cytoplasm (Figs. $6 \& 7$ ). In this case, the host cytoplasm was in direct contact with the parasitophorous matrix where the microfibrils were still well evident (Figs. $6 \& 7$ ).

After 10 to $15 \mathrm{~d}$ of incubation in filtered sea water the oocyst wall was devoid of the surrounding microfibrils. The ultrastructural organization of the sporozoites was also more visible. The sporozoite cell showed a multilaminar membrane just beneath the plasmalemma and numerous glycogen particles were evident (Fig. 9). Some oocysts were devoid of sporozoites and the wall showed a well-organized structure formed externally by a laminated layer and internally by a dense and homogeneous layer (Fig. 10). Sometimes free opercula (Fig, 10) and sporozoites were observed among free oocysts. No ultrastructural differences were found in the oocysts parasitizing the 2 bivalve species of Cerastoderme edule and Ruditapes decussatus from southern Portugal

\section{DISCUSSION}

The taxonomic and systematic states of gregarine species infecting crustacean and molluscan hosts seem poorly understood because of a lack of studies on their ultrastructure and life cycle history (Levine 1982). The ultrastructural morphology of the oocysts described in this work corresponds to a life cycle stage of an eugregarine species belonging to the family Porosporidae (Levine 1982).

These 2 parasite oocysts, which appear in 2 different host molluscan species, seem to present the same morphology and size. The oocysts, mainly their wall, conical operculum and opening as well as the uninucleated sporozoite observed in ultrathin serial sections, showed no ultrastructural differences.

On the other hand, the ultrathin serial sections show that each oocyst ('spore' as it is also named) (Cheng 1967) contains 1 sporozoite which enabled us to identify the genus Nematopsis. The lytic aspect observed in the host cells seems to be the result of the parasite activity which causes complete destruction of the gill cells in the immediate area in contact with the oocyst microfibrils. Dead and degenerating host cells occurring around the parasitophorous were easily recognized by their lysed appearance. Evident ultrastructural disruption of the plasmalemma that directly contacts the parasitophorous vacuole was frequently observed in advanced lysed cells. These data suggest that the high mortality seen in these bivalves, particularly Cerastoderme edule, is due to Nematopsis sp. Most of these apicomplexan parasites were found to be pathogenic to their hosts causing disintegration of cellular organization (Lauckner 1983). In these taxonomic groups, several species of gregarines have life cycle stages in different tissues of marine bivalves. The parasite described here may contribute to the previously described mortality due to the presence of Perkinsus

Figs. 1 to 5. Nematopsis sp. All aspects shown in LM and TEM were obtained in the host gill of Cerastoderme edule. Fig. 1. Living groups of oocysts of Nematopsis sp. (*) in host gill. $\times 1130$. Fig. 2. Ultrathin section of oocysts within the parasitophorous vacuoles $(\mathrm{PV})$ in direct contact with the host cytoplasm $(\mathrm{HC}) \times 5 \overline{760 .}$. Fig. 3. Uitrastructural aspect of a parasitophorous vacuole (PV) containing an oocyst (OO) with some sections of the same sporozoite (Sz). Nearby, the nucleus (Nu) of the host cells (HC) can be seen $\times 8600$. Figs. $4 \& 5$. Two aspects of longitudinal ultrathin sections of the apical zone showing the operculum (Op), wall (Wa) and irradiating microfibrils projected to the parasitophorous vacuole $(*) \times 39000$ and 44000 respectively 


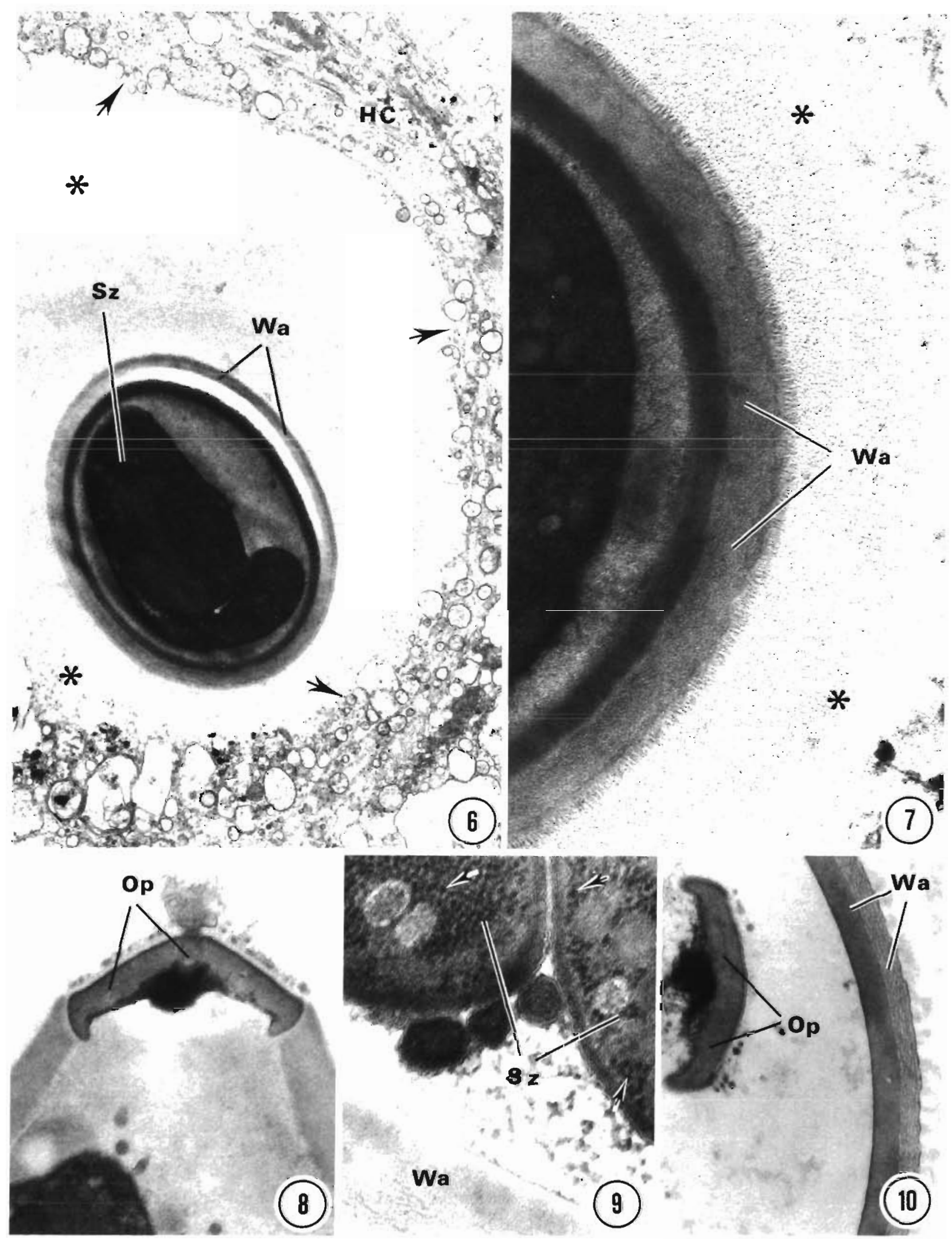


Figs. 6 to 10. Nematopsis sp. All aspects shown in LM and TEM were obtained in the host gill of Cerastoderme edule. Fig. 6 . Ultrathin section of an oocyst within the parasitophorous vacuole (*) that directly contacts the hyaloplasm of the host cell (HC). The latter shows some signs of lysis where the vacuole membrane disappears (arrows). $\times 12700$. Fig. 7 . Detail of the wall (Wa) and attached microfibrils projected to the parasitophorous vacuole $(*)$. The internal sporozoite presents high electron density. $\times 49000$. Fig. 8 . Detail of an ultrastructural aspect of the apical region of an oocyst where the operculum (Op), observed at the final phase of oocyst excystment, is well evident. The wall is devoid of microfibrillar layers. $\times 35000$. Fig. 9. Detail of the sporozoite $(\mathrm{Sz}$ ) and wall (Wa) ultrastructures. The (Sz) shows some dense vesicles and several glycogen particles (arrows). $\times 85000$. Fig. 10. Ultrastructural detail of the wall (Wa) and a free operculum (Op) observed after sporozoite excystment. $\times 35000$

atlanticus (Azevedo 1989a), Cryptosporidium sp. (Azevedo 1989b), endonucleobiotic bacteria (Azevedo 1989c) and Minchinia sp. (Azevedo \& Corral 1989) in Ruditapes decussatus from the same geographical area.

The lack of a complete life cycle, including the intermediate host, prevents the identification of the species that seems associated with cockle and clam mortalities in Portugal. Further detailed observations are needed to explain the complete life cycle and, consequently, the possible existence of other intermediate host species.

Acknowledgements. This work was partially supported by 'CME-INIC', 'DGQA and A. Almeida Foundation.

\section{LITERATURE CITED}

Azevedo, C. (1989a). Fine structure of Perkinsus atlanticus n. sp. (Apicomplexa, Perkinsea) parasite of the clam Ruditapes decussatus from Portugal. J. Parasitol. 75: $627-635$

Azevedo, C. (1989b). Ultrastructural observations of Cryptosporidium sp. parasite of Ruditapes decussatus (Mollusca, Bivalvia). J. Invert. Pathol. 54: 23-27

Azevedo, C. (1989c). Fine structure of endonucleobiotic bac-

Responsible Subject Editor: A. K. Sparks, Seattle, Washington, USA teria in the gill epithelium of Ruditapes decussatus. Mar Biol. 100: 339-341

Azevedo, C., Corral, L. (1989). Fine structural observations of the natural spore excystment of Minchinia sp. (Haplosporida). Eur. J. Protistol. 24: 168-172

Cheng, T C. (1967). Marine molluscs as hosts for symbiosis with a review of known parasites of commercially important species. In: Russell, F. S. (ed.) Advances in marine biology, Vol. 5. Academic Press, London, p. 134-177

Desportes, I., Vivarès, Ch. P., Théodoridès, J. (1977). Intérêt taxonomique de l'ultrastructure épicytaire chez Ganymedes Huxley, Porospora Schneider et Thiriotia n. g., eugrégarines parasites de crustacés. Ann. Sci. Nat. Zool., Paris 12 Série, Tome 19: 261-277

Lauckner, G. (1983). Diseases of Mollusca: Bivalvia. In: Kinne, O. (ed.) Diseases of marine animals, Vol. II. Biologische Anstalt Helgoland, Hamburg, p. 477-961

Levine, N. D. (1982). Apicomplexa. In: Parker, S. P. (ed.) Synopsis and classification of living organisms. Vol. 1 McGraw-Hill Book Company, New York, p. 571-587

Sprague, V (1970). Some protozoan parasites and hyperparasites in marine bivalve molluscs. In: Snieszko, S.F. (ed.) A symposium on diseases of fishes and shellfishes. Special Publ. no. 5. American Fisheries Society, Washington, D.C., p. 511-526

Théodoridès, J. (1962). Grégarines d'invertébrés marine de la région de Banyuls. I. Eugrégarines parasites de crustacés décapodes. Vie Milieu 13: 95-122

Vivarès, Ch. P. (1971). Les grégarines Porosporidae parasites des crustacés décapodes brachyoures méditerranéens. Vie Milieu 22: 55-68

Manuscript first received: June 15, 1991

Revised version accepted: June 16, 1992 